TUkEY, H. B. (1970). The leaching of substances from plants. Annual Review of Plant Physiology 21, 305324.

Watson, D. J., Thorne, G. N. \& French, S. A. W. (1963). Analysis of growth and yield of winter and spring wheats. Annals of Botany 27, 1-22.

\title{
GORRIGENDUM
}

\section{Water relations of winter wheat}

\section{Growth of the root system}

\section{By P. J. GREGORY, M. McGOWAN, P. V. BISCOE AND B. HUNTER}

Journal of Agricultural Science, Cambridge (1978), 91, 91-102

The authors regret the following errors:

Page 102, Appendix Table 1, lines 13, 15, 17, 20 and 22 of the Table should be amended as follows:

$\begin{array}{rrcrc}\text { Date } & \text { Leaf } & \begin{array}{c}\text { Stem + sheath } \\ + \text { hypocotyl }\end{array} & \text { Ear } & \begin{array}{r}\text { Total } \\ \text { shoot }\end{array} \\ \text { 13 May } & 137 & 183 & - & 320 \\ \text { 27 May } & 151 & 358 & - & 509 \\ \text { 10 June } & 184 & 694 & - & 878 \\ \text { 1 July } & 159 & 752 & 224 & 1135 \\ \text { 15 July } & 103 & 499 & 406 & 1009\end{array}$

